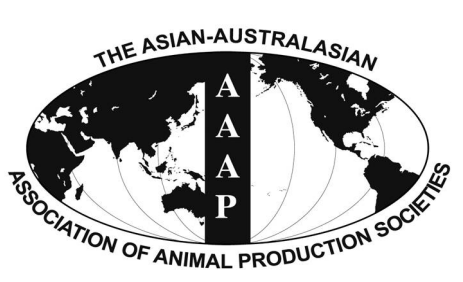

Open Access

Asian Australas. J. Anim. Sci.

Vol. 28, No. 11 : 1649-1656 November 2015

http://dx.doi.org/10.5713/ajas.15.0167

www.ajas.info

pISSN 1011-2367 elSSN 1976-5517

\title{
Monitoring of Chicken RNA Integrity as a Function of Prolonged Postmortem Duration
}

\author{
Yuwares Malila*, Yanee Srimarut, Juthawut U-chupaj ${ }^{1}$, Gale Strasburg ${ }^{2}$, and Wonnop Visessanguan \\ National Center for Genetic Engineering and Biotechnology, \\ National Science and Technology Development Agency, Khlong Luang, Pathum Thani 12120, Thailand
}

\begin{abstract}
Gene expression profiling has offered new insights into postmortem molecular changes associated with meat quality. To acquire reliable transcript quantification, high quality RNA is required. The objective of this study was to analyze integrity of RNA isolated from chicken skeletal muscle (pectoralis major) and its capability of serving as the template in quantitative real-time polymerase chain reaction (qPCR) as a function of postmortem intervals representing the end-points of evisceration, carcass chilling and aging stages in chicken abattoirs. Chicken breast muscle was dissected from the carcasses $(n=6)$ immediately after evisceration, and one-third of each sample was instantly snap-frozen and labeled as 20 min postmortem. The remaining muscle was stored on ice until the next rounds of sample collection ( $1.5 \mathrm{~h}$ and $6 \mathrm{~h}$ postmortem). The delayed postmortem duration did not significantly affect $\mathrm{A}_{260} / \mathrm{A}_{280}$ and $\mathrm{A}_{260} / \mathrm{A}_{230}(\mathrm{p} \geq 0.05)$, suggesting no altered purity of total RNA. Apart from a slight decrease in the $28 \mathrm{~s}: 18 \mathrm{~s}$ ribosomal RNA ratio in $1.5 \mathrm{~h}$ samples $(\mathrm{p}<0.05)$, the value was not statistically different between $20 \mathrm{~min}$ and $6 \mathrm{~h}$ samples $(\mathrm{p} \geq 0.05)$, indicating intact total RNA up to 6 h. Abundance of reference genes encoding beta-actin $(A C T B)$, glyceraldehyde 3-phosphate dehydrogenase $(G A P D H)$, hypoxanthineguanine phosphoribosyltransferase (HPRT), peptidylprolylisomerase A (PPIA) and TATA box-binding protein $(T B P)$ as well as meatquality associated genes (insulin-like growth factor 1 (IGF1), pyruvate dehydrogenase kinase isozyme 4 (PDK4), and peroxisome proliferator-activated receptor delta (PPARD) were investigated using qPCR. Transcript abundances of $A C T B, G A P D H, H P R T$, and $P P I A$ were significantly different among all postmortem time points $(\mathrm{p}<0.05)$. Transcript levels of $P D K 4$ and $P P A R D$ were significantly reduced in the $6 \mathrm{~h}$ samples $(\mathrm{p}<0.05)$. The findings suggest an adverse effect of a prolonged postmortem duration on reliability of transcript quantification in chicken skeletal muscle. For the best RNA quality, chicken skeletal muscle should be immediately collected after evisceration or within 20 min postmortem, and rapidly preserved by deep freezing. (Key Words: Gallus gallus, Skeletal Muscle, Postmortem Duration, RNA Integrity, Gene Expression)
\end{abstract}

\section{INTRODUCTION}

The quality of meat is markedly influenced by interactions between animal genotypes and environment particularly antemortem stress (Le Bihan-Duval, 2004). Investigation of gene expression can reveal insight information regarding molecular mechanisms associated

\footnotetext{
* Corresponding Author: Yuwares Malila. Tel: +66-2-117-8031, Fax: +66-2-117-8049, E-mail: yuwares.mal@biotec.or.th

${ }^{1}$ Department of Food Technology, Faculty of Agro-Industry, Prince of Songkla University, Hat Yai, Songkhla 90112, Thailand.

${ }^{2}$ Department of Food Science and Human Nutrition, Michigan State University, East Lansing, MI 48824, USA.

Submitted Feb. 26, 2015; Revised Apr. 20, 2015; Accepted May 4, 2015
}

with meat quality. Candidate genes can be subsequently identified for downstream applications on meat quality attributes, such as development of biomarkers for growth efficiency, mass enlargement, and meat quality improvement.

Gene expression analysis measures abundance of geneencoded mRNA. The accuracy of this technique to represent gene expression profile in the animals considerably relies on high quality and integrity of mRNA isolated from the tissue of interest (Bustin and Nolan, 2004; Fleige and Pfaffl, 2006; Mullen et al., 2006; Koppelkamm et al., 2011). Koppelkamm et al. (2011) monitored impact of decreased RNA integrity on reliability of quantitative real time polymerase chain reaction (qPCR) study for human 
cardiac, skeletal and brain tissues. They found that in the sample with degraded RNA material, it was possible to detect large change in expression; however, expression of genes with small fold-change tended to be misinterpreted.

It is generally accepted that the animal tissue collected immediately after slaughter is the ideal sample providing high quality of RNA samples. As postmortem duration proceeds, RNA is progressively degraded unless immediately preserved by deep freezing. However, this practice is difficult and inconvenient to execute in an actual industrial abattoir. The sampling process in the slaughterhouse can be performed after the process of feather removal or evisceration (20 min postmortem). Once the carcass is cut when the carcass temperature is still warm, the remaining parts cannot be taken back into the manufacturing line as it can induce microbial crosscontamination. If many biological replicates, e.g., more than 100 chickens, are required, several carcasses will be wasted. Sample collection would be more practical if it could be conducted after the chilling process $(1.5 \mathrm{~h}$ postmortem) or at the end of the manufacturing line.

RNA integrity is progressively degraded by endogenous nucleases as postmortem duration proceeds; however, recent studies of postmortem interval on RNA stability have shown RNA may be stable if the tissue samples have been handled appropriately. The degradation rate of RNA is tissue specific and species specific. Skeletal muscles of various species possess highly stable RNA. For example, Sanoudou et al. (2004) found no evidence of RNA degradation in autopsy specimens of human skeletal muscles collected up to $46 \mathrm{~h}$ postmortem. Fontanesi et al. (2008) investigated stability of RNA isolated from porcine skeletal muscle and found no evidence of RNA degradation up to $48 \mathrm{~h}$ postmortem. Moreover, the RNA was of sufficient quality for qPCR studies. Bahar et al. (2007) reported intact bovine skeletal muscle mRNA up to 22 days postmortem, and amplicons of beta-actin (ACTB), glyceraldehyde 3-phosphate dehydrogenase (GAPDH), and two diet-related genes from the $22 \mathrm{~d}$ postmortem samples that were detectable on agarose gel. Smooth muscle containing organs, such as pancreas, liver and kidney, and adipose tissue are rapidly degraded due to high content of RNases (Bahar et al., 2007; Koppelkamm et al., 2011). However, a study on RNA stability in Atlantic salmon reported that muscle RNA remained intact up to $8 \mathrm{~h}$ (Seear and Sweeney, 2008). Still, the literature provides promising evidence that RNA may still exhibit adequate quality for gene expression analysis in samples from which sample collection is extended.

Previous studies have shown evidence of extended RNA stability postmortem in other species; however, there are no reports on RNA stability in chicken skeletal muscle. Thus, the objective of this study was to evaluate RNA quality and integrity in chicken breast meat as a function of time postmortem to establish the possible utility of aging postmortem chicken muscle in gene profiling experiments.

\section{MATERIALS AND METHODS}

\section{Animal and sample collection}

Six Ross-308 broiler carcasses were purchased from a local abattoir (Nakhon Pathom, Thailand). Sample collection was performed at the abattoir. The broilers were slaughtered at $45 \mathrm{~d}$ of age (approximate carcass weight of 2.4 to $2.7 \mathrm{~kg}$ ) according to standard industry practice. Each chicken carcass was taken from the processing line immediately after evisceration (20 min postmortem). Skeletal muscle (pectoralis major) from one side of the breast was dissected from the carcass and the skin was removed. The sample was divided into 3 portions. The first portion was immediately diced into cubes with dimension of $1 \mathrm{~cm} \times 1 \mathrm{~cm} \times 1 \mathrm{~cm}$ using a sterile knife, placed in a sterile $50 \mathrm{~mL}$ conical centrifuge tube, and snap frozen in liquid nitrogen. This set of samples was labeled as chicken skeletal muscle at $20 \mathrm{~min}$ postmortem. The remaining breast muscle from the same breast side was placed in a clean polyethylene plastic bag and stored on ice until the next rounds of sample collection $(1.5 \mathrm{~h}$ postmortem and $6 \mathrm{~h}$ postmortem). The prolonged postmortem at $1.5 \mathrm{~h}$ and $6 \mathrm{~h}$ represented the end-points of chilling and aging steps, respectively. All tubes were kept in liquid nitrogen while the samples were transferred back to Food Biotechnology Laboratory, BIOTEC. Upon arrival, the samples were stored at $-80^{\circ} \mathrm{C}$, and used for RNA isolation. Based on their color, $\mathrm{pH}$ at $24 \mathrm{~h}$, drip loss, and cook loss (Table 1), which were determined from the other side of the breast according to the method described elsewhere (Eadmusik et al., 2011), the samples used in the study possessed neither discoloration nor abnormal water holding capacity (Woelfel et al., 2002; Garcia et al., 2010).

\section{RNA isolation}

Total RNA was isolated from chicken muscle samples using QIAzol lysis reagent (Qiagen Inc., Valencia, CA, USA) according to the manufacturer's instruction with a slight modification. Briefly, $200 \mathrm{mg}$ of frozen chicken

Table 1. Quality indices of chicken breast meat determined at $24 \mathrm{~h}$ postmortem

\begin{tabular}{lr}
\hline Quality index & p-value $^{1}$ \\
\hline Lightness $\left(\mathrm{L}^{*}\right)$ & $56.97 \pm 2.22$ \\
Redness $\left(\mathrm{a}^{*}\right)$ & $1.99 \pm 0.92$ \\
Yellowness $\left(\mathrm{b}^{*}\right)$ & $3.35 \pm 1.44$ \\
pH at $24 \mathrm{~h}$ & $5.99 \pm 0.08$ \\
Drip loss $(\%)$ & $0.71 \pm 0.24$ \\
Cook loss $(\%)$ & $23.20 \pm 3.40$ \\
\hline
\end{tabular}

${ }^{1}$ Mean \pm standard deviation calculated from 6 biological replicates. 
skeletal muscle was ground thoroughly into powder using a sterile mortar and pestle. The tissue powder was homogenized with $2.5 \mathrm{~mL}$ of QIAzol (Qiagen Inc., USA) for $40 \mathrm{~s}$, and the homogenate was subsequently centrifuged at $12,000 \times \mathrm{g}$ for $10 \mathrm{~min}, 4^{\circ} \mathrm{C}$. The supernatant was mixed with $0.2 \mathrm{vol}$ of chloroform and subsequently centrifuged at $12,000 \times \mathrm{g}$ for $10 \mathrm{~min}$ at $4^{\circ} \mathrm{C}$. The isolated RNA was precipitated by mixing $500 \mu \mathrm{L}$ of the aqueous phase with an equal volume of isopropanol followed by centrifugation at $12,000 \times \mathrm{g}$ for $8 \mathrm{~min}, 4^{\circ} \mathrm{C}$. The RNA pellet was collected, washed with $75 \%$ ethanol and re-suspended in nuclease-free water. The isolated RNA was treated with DNase I (Thermo Fisher Scientific Inc., Waltham, MA, USA) following company's protocol to remove any contaminated genomic DNA, and re-purified using QIAzol (Qiagen Inc., USA) according to the company's instruction. Quantity of total RNA was measured using a Nanodrop ND-1000 spectrophotometer (Thermo Fisher Scientific Inc., USA). Purity of the isolated RNA was determined according to relative absorbance at $260 \mathrm{~nm}$ to $280 \mathrm{~nm}\left(\mathrm{~A}_{260} / \mathrm{A}_{280}\right)$, and at $260 \mathrm{~nm}$ to $230 \mathrm{~nm}\left(\mathrm{~A}_{260} / \mathrm{A}_{230}\right)$.

\section{RNA integrity assessment}

Integrity of total RNA was determined by electrophoresis. In brief, $400 \mathrm{ng}$ of total RNA was mixed with $1 \mu \mathrm{L}$ of $6 \mathrm{X}$ DNA loading dye (Bio-Rad, Hercules, CA, USA). The RNA solution volume was adjusted to $6 \mu \mathrm{L}$ using nuclease-free water. The samples were separated on a $1 \%$ agarose gel with dimensions of $15 \mathrm{~cm} \times 11 \mathrm{~cm} \times 0.5 \mathrm{~cm}$ using a constant $75 \mathrm{~V}$ for $30 \mathrm{~min}$ at ambient temperature. The running buffer was $1 \times$ Tris/acetic acid/ethylenediaminetetraacetic acid, $\mathrm{pH} 8.0$ (Bio-Rad, USA). The gel was stained within $0.5 \mu \mathrm{g} / \mathrm{mL}$ ethidium bromide solution in the dark for $10 \mathrm{~min}$ at ambient temperature, and subsequently scanned using Gel Doc $\mathrm{XR}+$ System (Bio-Rad, USA). Images were acquired using Image Lab software (Bio-Rad, USA).

Analysis of the gel images was performed by densitometry using ImageJ 1.46r (Rasband, 2012). Two identical rectangular boxes were manually placed around the bands of $28 \mathrm{~s}$ and $18 \mathrm{~s}$ rRNA of the first lane. Features with the equal size were also used to measure the other bands of all lanes. The band intensity of 28s rRNA was divided with the same-lane 18s rRNA and expressed as ratio $28 \mathrm{~s}$ to $18 \mathrm{~s}(28 \mathrm{~s}: 18 \mathrm{~s})$. High integrity of RNA was generally denoted by two clean bands of $28 \mathrm{~s}$ and $18 \mathrm{~s}$ rRNA on the agarose gel with $28 \mathrm{~s}: 18 \mathrm{~s}$ equals to 2.0 (Sambrook et al., 1989).

\section{Synthesis of cDNA and qPCR}

Total RNA $(1.2 \mu \mathrm{g})$ was reverse transcribed into cDNA using iScript Select cDNA Synthesis Kit (Bio-Rad, USA) following the company's protocol. The oligo $(\mathrm{dT})_{20}$ was used as the primer for the amplification. The reverse transcription was performed in a DNA Engine DYAD ALD 1244 thermal cycler (MJ Research Inc., Waltham, MA, USA). The synthesized cDNA was purified using ethanol precipitation, re-suspended in nuclease-free water, and quantified with a Nanodrop ND-1000 (Thermo Fisher Scientific Inc., USA).

To evaluate whether an increased postmortem period affects capability of the isolated RNA to serve as the template in gene expression studies, qPCR of five common reference genes $(A C T B, G A P D H$, hypoxanthine-guanine phosphoribosyltransferase [HPRT], peptidylprolylisomerase A; PPIA, TATA box-binding protein $[T B P])$ and three

Table 2. Primers of genes chosen for quantitative real-time polymerase chain reaction

\begin{tabular}{|c|c|c|c|c|}
\hline $\begin{array}{c}\text { GenBank } \\
\text { accession number }\end{array}$ & Gene ID & Sequence (5' to $\left.3^{\prime}\right)$ & Amplicon length (bp) & $\mathrm{T}_{\mathrm{m}}\left({ }^{\circ} \mathrm{C}\right)$ \\
\hline NM_205518 & $A C T B$ & $\begin{array}{l}\text { F: CAAAGCCAACAGAGAGAAG } \\
\text { R: CATCACCAGAGTCCATCA }\end{array}$ & 137 & 83.5 \\
\hline NM_204305 & $G A P D H$ & $\begin{array}{l}\text { F: ACTTTGGCATTGTGGAGGGT } \\
\text { R: GGACGCTGGGATGATGTTCT }\end{array}$ & 131 & 86.0 \\
\hline NM_204848 & $H P R T$ & $\begin{array}{l}\text { F: CTCACAGGCTTCAACTCT } \\
\text { R: AATGACCAAGACGAGATTCT }\end{array}$ & 115 & 80.0 \\
\hline FJ977570.1 & $I G F 1$ & $\begin{array}{l}\text { F: TCTCAACATCTCACATCTCT } \\
\text { R: AAGCAGCACTTAACTAATTGT }\end{array}$ & 136 & 78.0 \\
\hline NM_001199909 & PDK4 & $\begin{array}{l}\text { F: TGCAATCACCAAAGGTCACCA } \\
\text { R: TGCAGTAGCTGAAGCTGTGTT }\end{array}$ & 87 & 79.0 \\
\hline NM_204728 & PPARD & $\begin{array}{l}\text { F: TCTCCAAGCACATCTACAA } \\
\text { R: CGGTCAAGATACCTCTCG }\end{array}$ & 75 & 78.5 \\
\hline NM_00166326 & PPIA & $\begin{array}{l}\text { F: GGCTCCCAGTTCTTCATC } \\
\text { R: ATCTGCTTGCTCGTCTTG }\end{array}$ & 143 & 88.5 \\
\hline NM_205103 & $T B P$ & $\begin{array}{l}\text { F: TGAATAGCACACGCACTA } \\
\text { R: GAGGCAACACATACTGAAC }\end{array}$ & 178 & 81.5 \\
\hline
\end{tabular}

$\mathrm{F}$, forward; $\mathrm{R}$, reverse; $\mathrm{T}_{\mathrm{m}}$, melting temperature. 
selected genes, including insulin-like growth factor (IGF1), pyruvate dehydrogenase kinase, isozyme 4 (PDK4) and peroxisome proliferator-activated receptor delta (PPARD), which were associated with meat quality (Malila et al., 2013), was performed. Primers of chicken genes (Table 2) were designed using Beacon Designer software (PREMIER Biosoft, Palo Alto, CA, USA). Primer specificity was confirmed by subjecting the primer sequence to a National Center for Biotechnology Information basic local alignment search tool nucleotide search. Only primers that specifically matched their respective genes were submitted for primer synthesis by Operon Biotechnologies Inc. (Cologne, Germany). Additional specificity was verified by dissociation curves with a single peak at melting temperature. The $20 \mu \mathrm{L}$ qPCR reactions included $25 \mathrm{ng}$ cDNA, $1 \mu \mathrm{M}$ primer mix, and $10 \mu \mathrm{L}$ of SsoAdvanced Universal SYBR Green supermix (Bio-Rad, USA) according to the manufacturer's instruction. For notemplate control, cDNA was substituted by $5 \mu \mathrm{L}$ of nuclease-free water. The reaction was performed in a Real Time PCR model BIORAD CFX96 (Bio-Rad, USA). The specificity of PCR products was confirmed by melting curve analysis. Threshold cycle $(\mathrm{Ct})$ was analyzed using Bio-Rad CFX Manager 2.1 software (Bio-Rad, USA) with a relative fluorescence unit (RFU) set at 100 RFU. Expression at $1.5 \mathrm{~h}$ or $6 \mathrm{~h}$ relative to 20 min postmortem was calculated using $2^{-\Delta \mathrm{Ct}^{\prime}}$ method for the reference genes, or $2^{-\Delta \Delta C t}$ method for the meat quality associated genes (Livak and Schmittgen, 2001).

\section{Statistical analysis}

All box plots were constructed using SigmaPlot 2001 ver. 7.0 (Systat Software Inc., San Jose, CA, USA). Statistical analysis was conducted using the SPSS ver. 11.5 (SPSS Inc., Chicago, IL, USA). One-way analysis of variance was used to evaluate difference in mean among postmortem time-points. The groups of data with significant difference in mean $(p<0.05)$ were subjected to Duncan's new multiple range test.

\section{RESULTS}

\section{Effect of an extent postmortem duration on quality of total RNA isolated from chicken skeletal muscle}

Quantity and purity of the total RNA isolated from chicken skeletal muscle obtained at different postmortem interval were determined by UV spectrophotometer (Figure 1). Yield of total RNA was $0.37 \pm 0.18 \mu \mathrm{g}$ per milligram of the frozen tissue. The average $\mathrm{A}_{260} / \mathrm{A}_{280}$ of $1.83 \pm 0.11$ (range, 1.61 to 1.93 ) indicates an absence of protein contamination in the isolated RNA. The $\mathrm{A}_{260} / \mathrm{A}_{230}$ of $0.94 \pm 0.41$ (range, 0.42 to 1.36 ) fell below the theoretically expected range of 1.8 to 2.0. The low value of $\mathrm{A}_{260} / \mathrm{A}_{230}$ implied that the isolated RNA solution contained remains of solvent, i.e. phenol, and chaotropic salt, i.e. guanidium isothiocyanate, which are present in phenol-based RNA extraction reagent (Cirera, 2013). Guanidium salt usually co-precipitates with RNA during precipitation with isopropanol at low temperature. The residuals strongly absorb light at $230 \mathrm{~nm}$, reducing the $\mathrm{A}_{260} / \mathrm{A}_{230}$ ratio. In this study, however, despite the low $\mathrm{A}_{260} / \mathrm{A}_{230}$ ratio, the total RNA was successfully reverse transcribed into cDNA. Thus, the contaminants did not detrimentally interfere with the downstream RNA application. Regarding effect of delayed postmortem duration on quality and purity of the total RNA, no significant differences in total RNA yield, $\mathrm{A}_{260} / \mathrm{A}_{280}$ and $\mathrm{A}_{260} / \mathrm{A}_{230}$ were found among the tissues collected at different time points $(\mathrm{p} \geq 0.05)$.

The effect of postmortem time on integrity of total RNA was assessed by agarose gel electrophoresis. Based on the

\section{B}

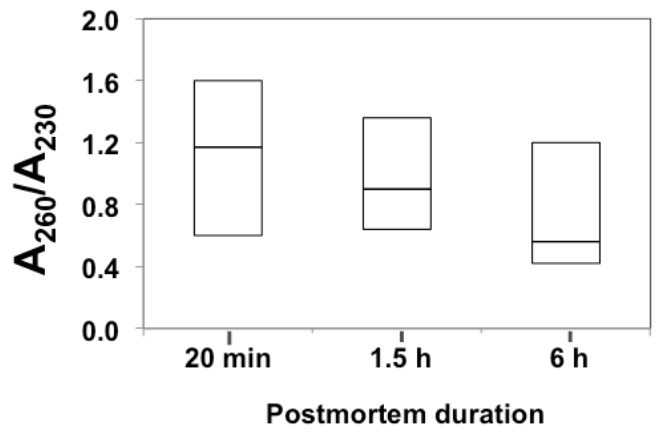

Figure 1. Box plots illustrate relative absorbance at $260 \mathrm{~nm}$ to $280 \mathrm{~nm}\left(\mathrm{~A}_{260} / \mathrm{A}_{280}\right)(\mathrm{A})$ and at $260 \mathrm{~nm}$ to $230 \mathrm{~nm}\left(\mathrm{~A}_{260} / \mathrm{A}_{230}\right)(\mathrm{B})$ of chicken breast muscle collected at different postmortem time-points. The box represents interquartile range. The top and the bottom of the box represent minimum and maximum values, while the horizontal lines within the box indicate median. Statistical parameters were calculated from three biological replicates. No significant difference in the values of $\mathrm{A}_{260} / \mathrm{A}_{280}$ or $\mathrm{A}_{260} / \mathrm{A}_{230}$ was found among postmortem duration $(\mathrm{p} \geq 0.05)$. 
A

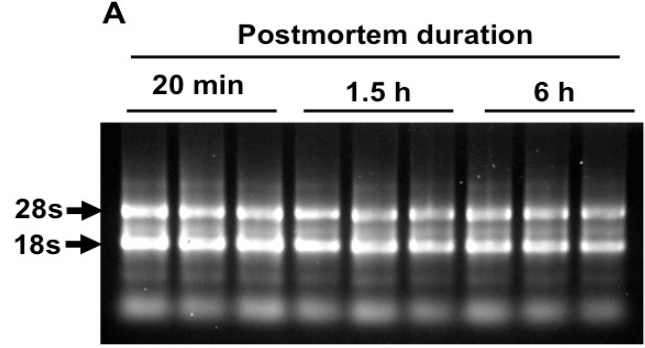

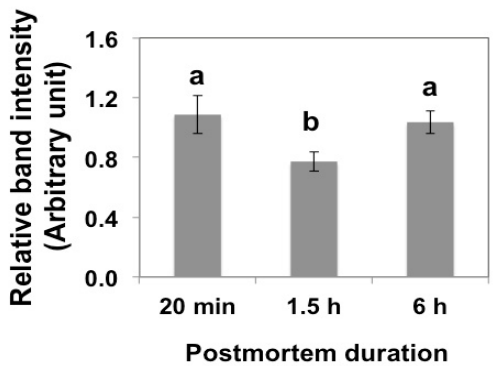

Figure 2. RNA integrity assessment using 1\% agarose electrophoresis. (A) Electrophoretic profiles of total RNA from chicken skeletal muscle obtained at different postmortem periods. In this figure, only electrophoretic patterns of three biological replicates were shown. (B) Histograms, constructed through densitometric analysis of electrophoretic results, represent mean \pm standard error of the mean of relative intensity of $28 \mathrm{~s}$ rRNA bands to $18 \mathrm{~s}$ rRNA bands calculated from six biological replicates. Different letters above the histograms indicate significant difference $(\mathrm{p}<0.05)$.

electrophoretic profiles (Figure 2A), two 28s and 18s rRNA bands were observed in all samples, indicating intact RNA. The relative intensity of those bands was calculated (Figure 2B). The average $28 \mathrm{~s}: 18 \mathrm{~s}$ ratios for $20 \mathrm{~min}$ and $6 \mathrm{~h}$ samples were $1.09 \pm 0.13$ and $1.04 \pm 0.08$, respectively. For the sample at $1.5 \mathrm{~h}$ postmortem, the $28 \mathrm{~s}: 18 \mathrm{~s}$ value $(0.77 \pm 0.06)$ was the lowest $(\mathrm{p}<0.05)$, suggesting some RNA degradation within the $1.5 \mathrm{~h}$ postmortem chicken samples compared to the other groups.

The postmortem interval influences chicken skeletal mRNA abundance

To evaluate the effect of delayed postmortem time on mRNA stability, the relative abundance of the selected genes was analyzed using qPCR. Genes commonly used as reference in $\mathrm{qPCR}$, and the genes associated with poultry meat quality were included in the analysis. Relative abundance describes change in abundance of the target genes in $1.5 \mathrm{~h}$ or $6 \mathrm{~h}$ postmortem samples relative to $20 \mathrm{~min}$ postmortem group.

Of five selected reference genes (Figure 3), abundance of $A C T B$ and HPRT was slightly higher at $1.5 \mathrm{~h}$ postmortem $(\mathrm{p}<0.05)$. At $6 \mathrm{~h}$ postmortem, however, abundances of $A C T B$ and HPRT reduced 0.7 and 0.4 fold, respectively $(\mathrm{p}<0.05)$. For $G A P D H$ and PPIA, abundance of those transcripts continuously decreased as a function of postmortem duration $(\mathrm{p}<0.05)$. In contrast, $T B P$ did not show statistically significant difference in abundance at all postmortem time points $(\mathrm{p} \geq 0.05)$. The results demonstrate the decreased mRNA levels of four out of five selected reference genes in the chicken skeletal muscle collected at 6 $\mathrm{h}$ postmortem. Due to its stability over the complete time interval, $T B P$ was used as an endogenous control gene to normalize expression of the meat-quality-associated genes.

As for the group of genes associated with chicken meat quality (Figure 4), a significant reduction of PDK4 and
PPARD transcript levels was observed in $6 \mathrm{~h}$ postmortem samples $(\mathrm{p}<0.05)$. However, abundance of $I G F 1$ did not significantly change overtime $(\mathrm{p} \geq 0.05)$. Altogether, prolonged postmortem duration adversely affects mRNA integrity of genes associated with quality of chicken pectoralis major muscle.

\section{DISCUSSION}

Advanced molecular methods such as microarrays, qPCR, and RNA-Seq have been integrated with meat science to fill knowledge gaps underlying genetics- and

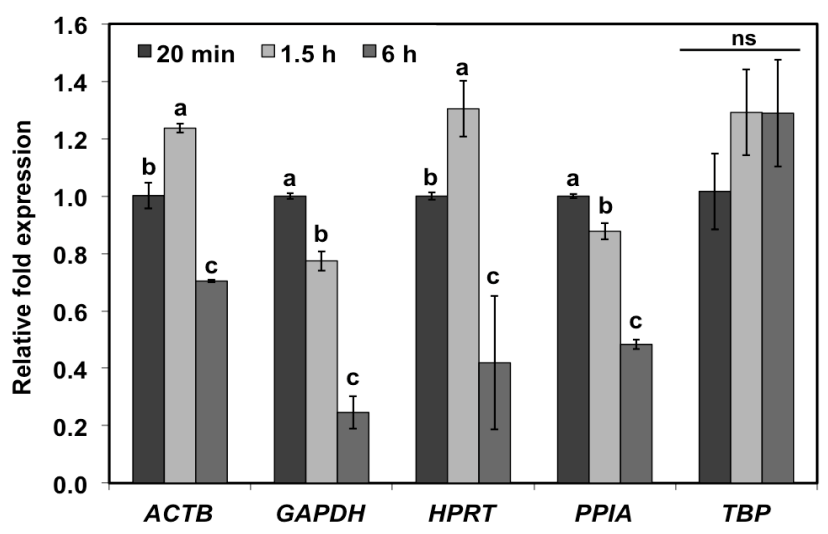

Figure 3. Transcript abundance of five reference genes in chicken skeletal muscle as postmortem extended. The chosen reference genes include beta-actin $(A C T B)$, glyceraldehyde 3-phosphate dehydrogenase $(G A P D H)$, hypoxanthice-guanine phosphoribosyltransferase (HPRT), peptidylprolylisomerase A (PPIA), and TATA box-binding protein $(T B P)$. Bars represent fold changes (mean \pm standard error of the mean) in expression of genes at $1.5 \mathrm{~h}$ or $6 \mathrm{~h}$ postmortem relative to $20 \mathrm{~min}$ postmortem. Relative fold expression of one gene was calculated using $2^{-\Delta \mathrm{Ct}^{\prime}}$ method, where $\Delta \mathrm{Ct}^{\prime}=\mathrm{Ct}_{1.5 \mathrm{~h} \text { or } 6 \mathrm{~h}}-\mathrm{Ct}_{20} \mathrm{~min}$. Different letters above the bars indicate significant difference $(\mathrm{p}<0.05)$ in expression of each gene at different time points $(\mathrm{p} \geq 0.05)$. 


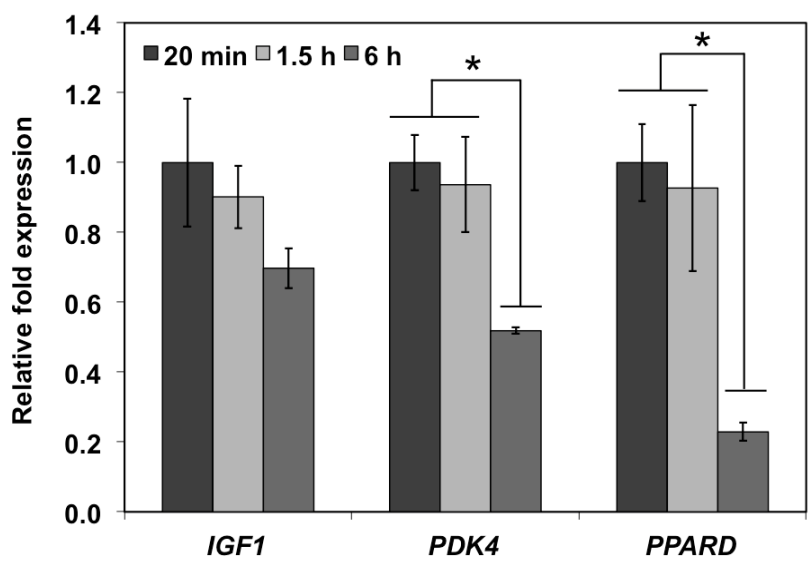

Figure 4. Abundance of transcripts encoded by genes associated with meat quality in chicken skeletal muscle as affected by delayed postmortem. Bars represent fold changes (mean \pm standard error of the mean) in expression of genes at $1.5 \mathrm{~h}$ or $6 \mathrm{~h}$ postmortem relative to the expression in the samples at $20 \mathrm{~min}$ postmortem. The genes of interest are insulin-like growth factor $(I G F 1)$, pyruvate dehydrogenase kinase, isozyme 4 (PDK4) and peroxisome proliferator-activated receptor delta (PPARD). TATA box-binding protein $(T B P)$ was used as a reference gene in the $2^{-\Delta \Delta \mathrm{Ct}}$ calculation. $* \mathrm{p}<0.05$.

environment-influenced molecular phenomena affecting postmortem changes and the ultimate quality of meat. Gene expression profiling is a useful approach in identifying genes associated with specific meat quality traits. The findings can be further utilized in development of biomarkers for desirable animal phenotypes. The accuracy of the technique relies on quality of intact RNA, but the materials progressively degrade over time (Bustin and Nolan, 2004). One of the challenges in gene expression analysis in poultry is the multi-step slaughtering process in an industrial abattoir that usually requires at least $15 \mathrm{~min}$ before a sample can be collected. The next end-point in the process is at the end of chilling stage ( $1.5 \mathrm{~h}$ postmortem). The delay in sample collection may impair RNA quality, and thus the apparent gene expression pattern. In this study, the quality and integrity of total RNA isolated from chicken pectoralis major muscle was determined as a function of postmortem time. The extent of postmortem interval was designed to mimic the end-points of meat manufacturing steps in the abattoir. The purity of the isolated RNA, as shown by the $A_{260} / A_{280}$ and $A_{260} / A_{230}$, was not significantly different among the samples collected at different postmortem interval. In addition, no statistical difference in electrophoretic pattern and the $28 \mathrm{~s}: 18 \mathrm{~s}$ band intensity were observed between chicken muscle samples collected at 20 min and $6 \mathrm{~h}$ postmortem, suggesting no loss of rRNA in the sample up to $6 \mathrm{~h}$.

Determining 28s:18s rRNA band intensity on agarose gels has been used as a primary characterization for RNA integrity. The $28 \mathrm{~s}: 18 \mathrm{~s}$ ratio of 2.0 typically denoted a high integrity RNA (Sambrook et al., 1989). However, the chicken RNA samples in the current study, displaying the $28 \mathrm{~s}: 18 \mathrm{~s}$ ratio between 0.8 and 1.1 on non-denaturing agarose gels, still successfully functioned in the subsequent cDNA synthesis and qPCR analysis. The evidence herein supports the study of Imbeaud et al. (2005) suggesting that the $28 \mathrm{~s}: 18 \mathrm{~s}$ ratio of 2.0 was difficult to meet for RNA derived from biological tissue, but total RNA with the rRNA ratio $\geq 1.0$ could be considered of good quality for downstream applications. Similar findings were observed in bovine (Bahar et al., 2007) and porcine (Fontanesi et al., 2008) skeletal muscle.

To assess integrity of mRNA as a function of prolonged postmortem duration, the total RNA was subjected to cDNA synthesis using oligo $(\mathrm{dT})_{20}$ as the primer. The synthesized cDNA was subsequently used as template in qPCR. Upon amplification of five housekeeping ( $A C T B, G A P D H, H P R T$, $P P I A$, and TBP) and three genes of interest (IGF1, PDK4, and $P P A R D)$, transcript abundance of the samples collected at $6 \mathrm{~h}$ postmortem substantially decreased $(\mathrm{p}<0.05)$, except for TBP transcript. As total RNA of each time point, for each biological replicate, was isolated from the same piece of chicken skeletal muscle, the reduced transcript abundance implied an impaired integrity of mRNA. It can be speculated that with increase in time postmortem, endogenous nucleases catalyzed RNA degradation, and might cleave the specific region for target gene priming. The primers might not be able to anneal to the template. Only a small amount of transcripts could be amplified, thus low SYBR green fluorescence emitted during qPCR analysis (Bustin and Nolan, 2004). Within 6 h postmortem, the catalysis might not remarkably reduce quantity of the intact rRNA population. Therefore, no change in the $28 \mathrm{~s}: 18 \mathrm{~s}$ band intensity was noticed.

Compared with chicken skeletal muscle, the stabilities of skeletal muscle RNA were much longer in cattle and pigs. Bahar et al. (2007) analyzed reference genes (GAPDH and $A C T B$ ) and diet-related genes (retinol binding protein 5 and stearoyl-CoA desaturase) in bovine skeletal muscle vacuum-packed and stored at $4{ }^{\circ} \mathrm{C}$. They reported uniform band intensities of PCR products of those genes on agarose gel over 22 days postmortem. In porcine skeletal muscle kept at $4^{\circ} \mathrm{C}$, RNA degradation appeared at $48 \mathrm{~h}$ postmortem (Fontanesi et al., 2008). It is apparent that impact of delayed postmortem duration depends on postmortem metabolic rate. Since bovine and swine postmortem metabolism takes place more slowly compared to poultry (de Fremery and Pool, 1960), their intact RNA was observed at longer postmortem duration. Besides, postmortem RNA degradation varies based on types of tissues. Bahar et al. (2007) documented a faster disintegration of RNA isolated from bovine liver and adipose tissue compared with skeletal muscle, and later reported a short stability of porcine colonic RNA subjected 
to $3 \mathrm{~h}$ ex vivo incubation (Bahar et al., 2012). Contrarily, Seear and Sweeny (2008) observed in Atlantic salmon (Salmo salar L.) a lower stability of RNA of muscle compared with kidney, brain and liver.

The ultimate goal of this study was to ascertain the most suitable step for collecting chicken muscle samples that still exhibit adequate quality for a subsequent gene expression study. As sample collection after evisceration step was inconvenient and wasteful, the initial objective was to test the possibility of using chicken muscle collected after carcass chilling or aging steps in transcript quantification. The chicken muscle collected at 20 min showed the best quality of RNA. However, RNA from the muscle collected at $1.5 \mathrm{~h}$ postmortem, representing the chicken collected after chilling process, might possess adequate quality to be investigated for certain genes, such as PDK4 and PPARD, but not be suitable for transcriptome analysis as abundance of some genes might be reduced due to partial RNA degradation. For the sample collected at $6 \mathrm{~h}$ postmortem, mimicking the samples after aging step, only $T B P$ and $I G F 1$ levels were not affected by the delay sample collection. It is recommended that if prolonged postmortem chicken muscle tissue must be used in such investigation, a preliminary experiment should be conducted to inspect the effect of the delayed sample collection on mRNA stability of gene of interest.

In conclusion, the effects of prolonged postmortem interval on integrity chicken skeletal muscle RNA and its reliability for use in gene expression analysis were evaluated. The investigation indicated a stability of total RNA up to $6 \mathrm{~h}$ postmortem. However, transcript abundance of reference genes, including $A C T B, G A P D H, H P R T$, and $P P I A$ genes significantly changed when RNA was isolated from the muscle stored on ice for $1.5 \mathrm{~h}$ and $6 \mathrm{~h}$. Transcript level of the selected genes associated with meat quality remained unchanged at $1.5 \mathrm{~h}$ postmortem, but $P D K 4$ and PPARD abundance of the $6 \mathrm{~h}$ samples significantly decreased. The longer postmortem period adversely affected integrity of mRNA isolated from chicken skeletal muscle. To preserve the best quality of RNA aimed for subsequent gene expression study, particularly transcriptome analysis, chicken skeletal muscle should be immediately collected after evisceration or within $20 \mathrm{~min}$ postmortem.

\section{CONFLICT OF INTEREST}

We certify that there is no conflict of interest with any financial organization regarding the material discussed in the manuscript.

\section{ACKNOWLEDGMENTS}

The authors are appreciative of kind assistance and facilitation of Wichakarn Farm (Nakhon Pathom, Thailand) during sample collection. This project was financially supported by National Center for Genetic Engineering and Biotechnology, Thailand with grant number P-14-50559. Juthawut U-chupaj is grateful for the financial support from the Royal Golden Jubilee Ph.D. program (Grant No. PHD/0282/2551), the Thailand Research Fund, Thailand.

\section{REFERENCES}

Bahar, B., F. J. Monahan, A. P. Moloney, O. Schmidt, D. E. MacHugh, and T. Sweeney. 2007. Long-term stability of RNA in post-mortem bovine skeletal muscle, liver and subcutaneous adipose tissues. BMC Mol. Biol. 29:108.

Bahar, B., J. V. O'Doherty, and T. Sweeney. 2012. Assessment of RNA integrity in the postmortem pig colonic tissue ex vivo. J. Anim. Sci. 90 Suppl 4:22-24.

Bustin, S. A. and T. Nolan. 2004. Pitfalls of quantitative real-time reverse-transcription polymerase chain reaction. J. Biomol. Tech. 15:155-166.

Cirera, S. 2013. Highly efficient method for isolation of total RNA from adipose tissue. BMC Res. Notes. 6:472.

de Fremery, D. and M. F. Pool. 1960. Biochemistry of chicken muscle as related to rigor mortis and tenderization. J. Food Sci. 25:73-87.

Eadmusik, S., C. Molette, X. Fernandez, and H. Rémignon. 2011. Are one early muscle $\mathrm{pH}$ and one early temperature measurement sufficient to detect PSE breast meat in turkeys? Br. Poult. Sci. 52:177-188.

Fleige, S. and M. W. Pfaffl. 2006. RNA integrity and the effect on the real-time qRT-PCR performance. Mol. Aspects Med. 27:126-139.

Fontanesi, L., M. Colombo, F. Beretti, and V. Russo. 2008. Evaluation of post mortem stability of porcine skeletal muscle RNA. Meat Sci. 80:1345-1351.

Garcia, R. G., L. W. de Freitas, A. W. Schwingel, R. M. Farias, F. R. Caldara, A. M. A. Gabriel, J. D. Graciano, C. M. Komiyama, and I. C. L. Almedia Paz. 2010. Incidence and physical properties of PSE chicken meat in a commercial processing plant. Rev. Bras. Cienc. Avic. 12:233-237.

Imbeaud, S., E. Graudens, V. Boulanger, X. Barlet, P. Zaborski, E. Eveno, O. Mueller, A. Schroeder, and C. Auffray. 2005. Towards standardization of RNA quality assessment using user-independent classifiers of microcapillary electrophoresis traces. Nucl. Acids Res. 33:e56.

Koppelkamm, A., B. Vennemann, S. Lutz-Bonengel, T. Fracasso, and M. Vennemann. 2011. RNA integrity in post-mortem samples: influencing parameters and implications on RT-qPCR assays. Int. J. Legal Med. 125:573-580.

Le Bihan-Duval, E. 2004. Genetic variability within and between breeds of poultry technological meat quality. Worlds Poult. Sci. J. 60:331-340.

Livak, K. J. and T. D. Schmittgen. 2001. Analysis of relative gene expression data using real-time quantitative PCR and the $2^{-\triangle \Delta C T}$ Method. Methods 25:402-408.

Malila, Y., R. J. Tempelman, K. R. Sporer, C. W. Ernst, S. G. Velleman, K. M. Reed, and G. M. Strasburg. 2013. Differential gene expression between normal and pale, soft, and exudative 
turkey meat. Poult. Sci. 92:1621-1633.

Mullen, A. M., P. C. Stapleton, D. Corcoran, R. M. Hamill, and A. White. 2006. Understanding meat quality through the application of genomic and proteomic approaches. Meat Sci. 74:3-16.

Rasband, W. S. 2012. ImageJ. U. S. National Institutes of Health. http://imageJ.nih.gov/ij/. Accessed September 9, 2014.

Sambrook, J., E. F. Fristsch, and T. Maniatis. 1989. Molecular Cloning: A Laboratory Manual. 2nd ed. Cold Spring Harbor Laboratory Press, New York, NY, USA.
Sanoudou, D., P. B. Kang, J. N. Haslett, M. Han, L. M. Kunkel, and A. H. Beggs. 2004. Transcriptional profile of postmortem skeletal muscle. Physiol. Genomics 16:222-228.

Seear, P. J. and G. E. Sweeney. 2008. Stability of RNA isolated from post-mortem tissues of Atlantic salmon (Salmo salar L.). Fish Physiol. Biochem. 34:19-24.

Woelfel, R. L., C. M. Owens, E. M. Hirschler, R. MartinezDawson, and A. R. Sams. 2002. The characterization and incidence of pale, soft, and exudative broiler meat in a commercial processing plant. Poult. Sci. 81:579-584. 